\title{
$\mathrm{SCW}$ 형 지중 열교환기의 지중 열전도도 해석에서 초기제외시간 결정에 관한 연구
}

\section{A Study on the Determining Initial Ignoring Time for the Analysis of Ground Thermal Conductivity of SCW Type Ground Heat Exchanger}

\author{
장근선(Keun-Sun Chang) ${ }^{1}$, 김민준(Min-Jun Kim) $)^{2^{+}}$, 김영재(Young-Jae Kim) ${ }^{3}$ \\ ${ }^{1}$ 선문대학교 기계공학과, ${ }^{2}$ 선문대학교 대학원 기계공학과, ${ }^{3}$ 선문대학교 환경생명화학공학과 \\ ${ }^{1}$ Department of Mechanical Engineering, SunMoon University, Chungnam 336-708, Korea \\ ${ }^{2}$ Department of Mechanical Engineering, Graduate School of SunMoon University, Chungnam 336-708, Korea \\ ${ }^{3}$ Department of Environmental and Bio-chemical Engineering, SunMoon University, Chungnam 336-708, Korea
}

(Received June 3, 2014; revision received July 30, 2014; Accepted: August 4, 2014)

\begin{abstract}
This paper presents an analysis on the initial ignoring time of SCW type GHX using Mean Square Error method. Line source method is a useful method for estimating the ground thermal conductivity for the vertical type and SCW type GHX in Korea. The line source method for ground thermal conductivity of geothermal in-site test is the basis of linear approximation between the temperature of a borehole and logarithmic time in a GHX. To apply the line source method to the estimation of SCW type GHX, it is necessary to ignore the initial time of data at the stage of a linear approximation. This paper proposed a new initial ignoring time of SCW type GHX among various initial ignoring time at the time for reaching MSE of $0.02{ }^{\circ} \mathrm{C}^{2}$.
\end{abstract}

Key words SCW(Standing Column Well), GHX(Ground heat exchanger), Mean Square Error method(평균자승오차법), Line source method(라인소스방법), Ground thermal conductivity(지중 열전도도)

† Corresponding author, E-mail: mjkim@kraac.or.kr

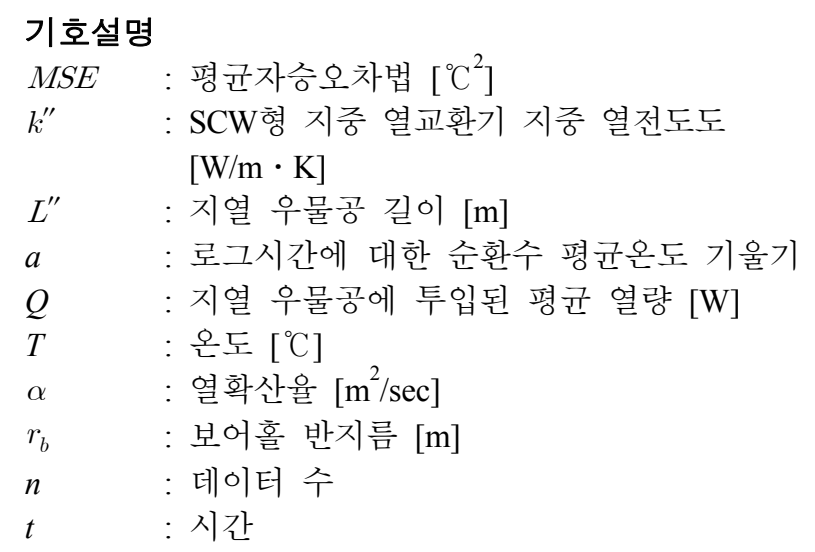

\section{1. 서 론}

최근 지열원 열펌프 시스템의 보급이 증가하면서 고심도 대용량의 지중 열교환기에 대한 관심이 높아 지고 있다. 이러한 고심도 대용량의 지중 열교환기로 현재 에너지관리공단 신재생에너지센터에서는 Standing Column Well(이하 SCW형) 지중 열교환기를 보급하고 있으며 그 수요 또한 증가하고 있는 추세이다.

$\mathrm{SCW}$ 형 지중 열교환기는 수직으로 지중에 우물공을 설치하고 우물공으로부터 지하수를 취수하여 열폄프의 열원으로 사용하고 지하수를 다시 동일한 우물공으로 주입하는 방식의 지중 열교환기를 말한다. 현재 국내에 서는 $\mathrm{SCW}$ 형 지중 열교환기의 지중 열전도도를 평가하 기 위한 방법으로 수직 밀폐형 지중 열교환기와 동일한 라인소스방법(Line Source Method)이 적용되고 있다. ${ }^{(1)}$

라인소스방법은 보어홀 유체의 온도가 대수시간에 관하여 직선식이 되는 특성을 이용하여 $\mathrm{k}$ 값을 구하는 
데 직선식은 근사화 과정을 통하여 이루어진다. 이러 한 직선식의 근사화를 얻기 위해서는 시험데이터에서 초기에 얻어진 데이터 일부를 제외하고 나머지 데이터 에서 직선식을 유도한다. 이때 초기에 얻어진 데이터 를 제외하는 시간을 초기제외시간(IIT : Initial Ignoring Time)이라 한다.

$\mathrm{Gehlin}^{(2)}$ 에 의하면 라인소스방법을 적용하기 위해서 는 \%error가 $\tau=\frac{\alpha t}{r_{b}^{2}}=5$ 에서 약 $2 \%$ 의 오차를 보이며 그 이상에서는 오차값이 더 작아진다고 하였다. 이는 수직 밀폐형 지중 열교환기 $(150 \mathrm{~mm})$ 의 경우 화강암 지반에서 약 $t=5.6 \mathrm{hr}$ 을 보인다. Ingersoll et al. ${ }^{(3)}$ 은 파 이프 직경이 $4 \mathrm{inch}(100 \mathrm{~mm})$ 보다 작고 24시간 보다 긴 시간의 데이터에서 라인소스방법의 적용이 가능하다 고 하였다.

그러나 보어홀의 직경이 수직 밀폐형보다 크게 적용 되어지는 $\mathrm{SCW}$ 형 지중 열교환기 $(200 \sim 250 \mathrm{~mm})$ 의 경우 이론상으로 초기제외시간이 더 크게 적용되어져야 한다. 또한 국내에서 진행되는 $\mathrm{SCW}$ 형 지중 열교환기의 현장 열응답시험은 데이터 취득시간이 24시간 이상 확보하여 도 파이프구경이 너무 커서 적용하기 어렵다는 결론이 된다.

하지만 $\mathrm{SCW}$ 형 지중 열교환기는 보어홀 내부에 $\mathrm{PE}$ 파이프와 그라우팅재가 삽입되지 않고 지하수와 암반 이 직접 열을 교환하기 때문에 현장열응답시험에서 획 득한 데이터를 분석해보면 수직 밀폐형 지중 열교환기 시험데이터 보다 안정화 되는데 시간이 더 짧게 나타 나고 있다.

Lee et al. ${ }^{(4)}$ 은 수직 밀폐형 지중 열교환기에서 라인소스 방법을 적용하기 위한 초기제외시간을 계산함에 있어 평균자승오차법을 이용하여 검토하였으며, 현재 에너지 관리공단에서 사용되어지는 수직 밀폐형 지중 열교환기 의 초기제외시간으로 12 시간이 적당하다고 평가하였다.

현재 국내에서는 $\mathrm{SCW}$ 형 지중 열교환기의 지중 열 전도도를 계산하기 위한 방법으로 라인소스방법을 적 용하고 있으며, 이때 해석을 위해 시험데이터의 초기 제외시간을 2시간으로 적용하고 있으나 초기제외시간 에 대한 연구가 정확하게 이루어지진 않았다.

따라서 본 연구에서는 현장열응답시험에서 얻은 시험 데이터를 바탕으로 평균자승오차법을 적용하여 $\mathrm{SCW}$ 형 지중 열교환기에 적절한 초기제외시간에 대하여 연 구하고자 한다.

\section{2. 실험장치 및 방법}

\section{1 평균자승오차법}

Lee et al. ${ }^{(4)}$ 은 수직 밀폐형 지중 열교환기에서 현장열
응답시험을 통하여 습득된 데이터를 이용하여 $T_{f}-\ln t$ 의 관계식이 직선식으로부터 얼마나 이탈을 보이는가 를 정량적으로 해석하고 그 해석결과로부터 초기제외 시간을 결정하는 방식을 통해 라인소스방법의 신뢰성을 높이고자 하였다. 그들은 이러한 해석방법을 오차해석 이라 명명하였으며 다음과 같은 순으로 진행하였다.

(1) 열응답시험시간 $\mathrm{t}_{1} \sim \mathrm{t}_{2}$ 사이에 $\Delta t$ 간격으로 측정된 자 료를 $T_{f}-\ln t$ 의 좌표상에 나타내고 선형최소자승법 (line least square method)을 이용하여 직선식을 구 한다.

(2) 측정된 온도와 동일한 시간에 직선식에서 계산된 온도와의 차이를 자승한다.

(3) 측정된 모든 점에서 위와 같이 온도차의 자승을 구 하여 합한 후 이 총합을 총 측정개수로 나누어 구 한 값을 라인소스방식의 평균자승오차 MSE(Mean Square Error)로 정의한다.

총 측정된 데이터의 개수가 $\mathrm{n}$ 개이고 각 점에서의 측 정온도를 $T_{m . i}$, 동일시간에 직선식에서의 온도를 $T_{l . i}$ 라 고 하면 MSE는 다음과 같이 표현할 수 있다.

$$
M S E=\frac{\sum_{i=1}^{n}\left(T_{m . i}-T_{l . i}\right)^{2}}{n}
$$

이렇게 구해진 MSE의 값은 $t_{2}$ 를 고정시킨 상태에서 $t_{1}$ 을 변화시킴에 따라 그 값이 달라질 수 있다. 즉 MSE 는 $t_{1}$ 의 함수가 되며 원하는 초기제외시간을 $t_{1}$ 으로 정 하면 $t_{1}$ 에 따라 MSE 값의 변화 경향을 볼 수 있으며 이에 따라 초기제외시간을 정할 수 있다.

\section{2 지중 열전도도 측정시험}

지중 열전도도 시험방법은 지식경제부 고시 2012-7호(1) 에 잘 정리되어 있으며, Table 1은 수직 밀폐형과 $\mathrm{SCW}$ 형 지중 열교환기 지중 열전도도 측정시험조건을 보여 주고 있다. 국내 지열원 열펌프 시스템에 적용되어지 는 수직 밀폐형 지중 열교환기의 경우 천공심도가 150 $200 \mathrm{~m}$ 가 주를 이루는 반면 SCW형의 경우 $300 ~ 500 \mathrm{~m}$ 가 주를 이룬다.

수직 밀폐형과 $\mathrm{SCW}$ 형 지중 열교환기의 시험방법은 크게 차이를 보이지 않지만 수직 밀폐형의 경우 투입 열량(2관식 기준)이 $(50 \sim 80) \mathrm{W} / \mathrm{m}$ 로 작은 반면 $\mathrm{SCW}$ 형 의 경우 투입열량이 지열 우물공 길이당(200 500) W/m 으로 수직 밀폐형의 최소 4 배 이상 크다.

시험에서 투입열량의 표준편차는 수직 밀폐형과 $\mathrm{SCW}$ 
Table 1 Ground heat exchanger test condition

\begin{tabular}{|c|c|c|c|c|}
\hline & \multirow{2}{*}{\multicolumn{2}{|c|}{ Item }} & \multicolumn{2}{|c|}{ test condition } \\
\hline & & & vertical type & SCW type \\
\hline \multirow{4}{*}{$\begin{array}{l}\text { measurement } \\
\text { time }\end{array}$} & 1 & begin test & $\begin{array}{l}\text { after } 72 \mathrm{hr} \text { at complete bentonite grouting } \\
\text { and after } 14 \text { days cement grouting }\end{array}$ & after $72 \mathrm{hr}$ at complete borehole \\
\hline & 2 & initial ignoring time & start test after $12 \mathrm{hr}$ & start test after $2 \mathrm{hr}$ \\
\hline & 3 & test duration & more than $48 \mathrm{hr}$ & more than $24 \mathrm{hr}$ \\
\hline & 4 & data acquisition & \multicolumn{2}{|c|}{ below $10 \mathrm{~min}$} \\
\hline \multirow{2}{*}{$\begin{array}{l}\text { measurement } \\
\text { condition }\end{array}$} & 5 & injection heat capacity & (2 tube) $50 \sim 80 \mathrm{~W} / \mathrm{m}$ & $200 \sim 500 \mathrm{~W} / \mathrm{m}$ \\
\hline & 6 & Loop in/out $\mathrm{dT}$ & \multicolumn{2}{|c|}{$3.5 \sim 7.0^{\circ} \mathrm{C}$} \\
\hline \multirow{2}{*}{$\begin{array}{l}\text { measurement } \\
\text { error }\end{array}$} & 7 & Temperature & \multicolumn{2}{|c|}{$\begin{array}{l} \pm 0.3^{\circ} \mathrm{C} \text { below } \\
\text { (standard deviation toward average temperature) }\end{array}$} \\
\hline & 8 & injection heat capacity & $\begin{array}{c} \pm 3.0 \% \text { below } \\
\text { (standard deviation toward average } \\
\text { power) }\end{array}$ & $\begin{array}{l} \pm 3.0 \% \text { below } \\
\text { (standard deviation toward average } \\
\text { heat capacity) }\end{array}$ \\
\hline remeasurement & 9 & begin remeasurement & \multicolumn{2}{|c|}{ recovery $3.0 \%$ below of ground initial temperature } \\
\hline
\end{tabular}

형 모두 $\pm 3 \%$ 이내로 정의 되어있다. 하지만 순환수가 지중 열교환기를 한 바퀴 순환하는데 걸리는 시간이 10 분 이내로 짧은 수직 밀폐형의 경우 투입열량에 대 한 순환수 온도변화가 작게 나타나지만 $\mathrm{SCW}$ 형의 경 우는 우물공 내부에 삽입되는 심정펌프 모델이 일반화 되어 있어 순환수량이 한정적이며, 우물공 내부 물량 이 많아 한바퀴 순환하는데 걸리는 시간이 약 1 시간 정도 걸림으로 투입열량의 표준편차는 $2 \%$ 이내를 유지 하는 것이 바람직하다.

또한 수직 밀폐형의 경우 초기제외시간이 시험시작 후 12 시간이 적용되어지나 $\mathrm{SCW}$ 형은 2 시간이 적용되 고 있다.

\subsection{SCW형 지중 열교환기 지중 열전도도 산출}

현재 $\mathrm{SCW}$ 형 지중 열교환기의 지중 열전도도는 수 직 밀폐형과 같은 라인소스방법(Line source method)을 이용하고 있으나 수직 밀폐형 지중 열교환기와는 지중 열교환기의 길이를 산출하는 방법에 있어 다소 차이를 보인다. 수직 밀폐형의 경우 $\mathrm{PE}$ 파이프의 삽입깊이를 지중 열교환기 길이로 사용되어지나 $\mathrm{SCW}$ 형 지중 열 교환기의 경우 지하수 수위 형성이 지역적으로 차이를 보일 뿐만 아니라 유공관 설치길이도 서로 상이하기 때문에 우물공의 천공깊이를 열교환기 길이로 사용하 는 것은 적절하지 않다.

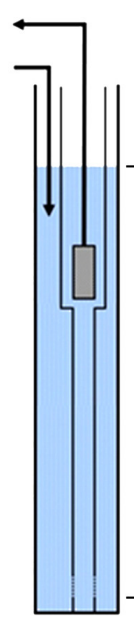

(a)

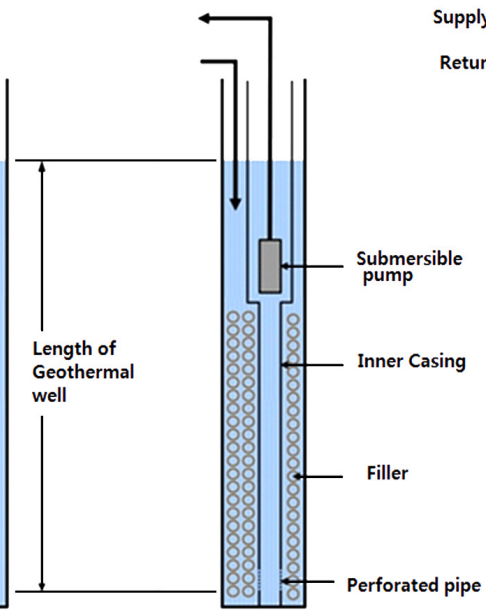

(b)

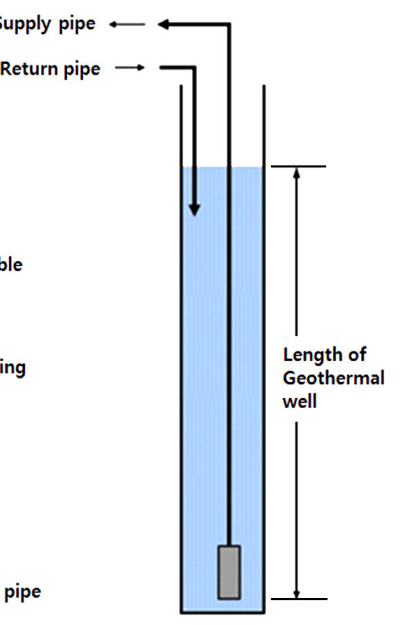

(c)

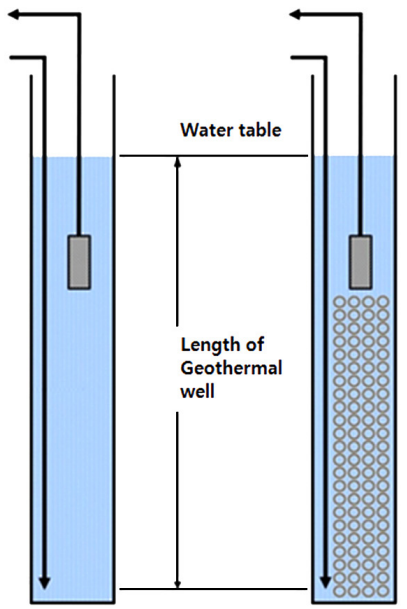

(d) (e)

Fig. 1 Various SCW type ground heat exchanger in Korea. 
Fig. 1은 국내에 적용되고 있는 $\mathrm{SCW}$ 형 지중 열교환 기의 종류를 보여주고 있다. 그림에서 (a), (b) 형상은 우물공 내부에 내부케이싱 $(\mathrm{PVC}=125 \mathrm{~A})$ 이 설치되어 심정펌프가 내부케이싱 안쪽에 삽입되는 구조이며, (c) 형상은 우물공 내부에 내부케이싱이 존재하지 않으며 우물공 하단에 심정펌프가 설치된 구조이다. (d), (e) 형상은 우물공 상단에 심정펌프가 설치되고 환수관이 우물공 최하단에 설치된 구조이다. (a), (b), (c) 형상의 $\mathrm{SCW}$ 형 지중 열교환기는 지하수위로 순환수가 환수되 어 열교환기 하단으로 이동하면서 암반과 열교환을 하 는 방식이며, (d), (e) 형상의 지중 열교환기는 우물공 최하단에 순환수가 환수되어 심정펌프 방향으로 이동 하면서 암반과 열교환하는 방식이다. (b), (e) 형상의 지중 열교환기는 우물공 내부에서 순환수의 열전달을 향상시키고, 우물공의 공무너짐을 방지하기 위해 채움 재를 삽입한 방식이다.

따라서 본 연구에서는 $\mathrm{SCW}$ 형 지중 열교환기 내부 에서 실제 지하수가 유동하는 거리 즉, 지하수 수위에 서부터 유공관 끝단까지의 거리를 지중 열교환기의 길 이로 정의하였다. 식(1)은 $\mathrm{SCW}$ 형 지중 열교환기의 지 중 열전도도 계산식을 보여주고 있다.

$$
k^{\prime \prime}=\frac{Q}{4 \pi \cdot L^{\prime \prime} \cdot a}[W / m K]
$$

위 식에서 $k^{\prime \prime}$ 는 $\mathrm{SCW}$ 형 지중 열교환기의 지중 열전 도도을 나타내며, $\mathrm{Q}$ 는 지열 우물공에 투입된 평균 열 량, $\mathrm{a}$ 는 열량투입 후 초기 2시간을 제외한 데이터에서 로그시간에 대한 순환수 평균온도 변화에 대한 직선의 기울기, $L^{\prime \prime}$ 은 지열 우물공의 길이로 지하수 수위에서 부터 유공관 끝단까지의 길이를 말한다.

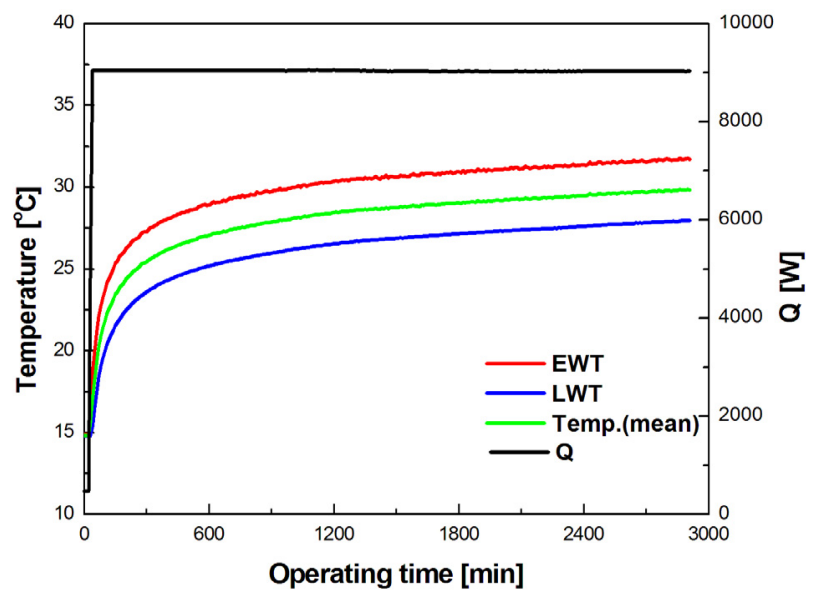

Fig. 2 Test data of vertical close-loop type ground heat exchanger.

\section{3. 실험결과 및 고찰}

\section{1 수직 밀폐형 지중 열교환기의 오차해석}

본 연구에서는 $\mathrm{SCW}$ 형 지중 열교환기의 오차해석의 정확도를 살펴보기 위해 수직 밀폐형 지중 열교환기의 현장열응답시험에서 측정된 데이터를 이용하여 MSE 분석을 하였다. Fig. 2는 수직 밀폐형 지중 열교환기의 시험데이터를 보여주고 있다. 시험데이터에서 투입열 량은 $(9.05 \pm 0.02) \mathrm{kW}$ 로 안정적으로 공급되었으며, 이 때 순환수 평균온도를 이용하여 오차해석을 수행하였 다. 현재 에너지관리공단 신재생에너지센터에서 운영 하는 지침에서는 수직 밀폐형 지중 열교환기에 경우 순환수에 열량투입 후 초기 12 시간 데이터를 제외하고 나머지 데이터를 이용하여 온도곡선 기울기를 산출하 게 되어 있다. Fig. 3 은 수직 밀폐형 지중 열교환기 데 이터를 이용하여 해석한 그래프를 보여주고 있다. 그래 프에서 빨간선이 Fig. 2 그래프를 이용한 실선이다. 그 래프를 보면 MSE 값이 $0.01{ }^{\circ} \mathrm{C}^{2}$ 이 되는 시간이 열량투입 후 약 6 시간으로 나타났다. 현재 수직 밀폐형 지중 열교 환기에 열량을 공급하기 위한 방법으로 발전기와 한전수 전이 이용되고 있으며 한전수전(kepco electic power)을 이용하는 경우 투입열량에 변동 폭이 발전기를 사용하 는 시험보다 크게 나타난다. 그래프에서 3 가지 경우에 한전수전을 이용한 시험에서의 데이터를 이용하여 해 석한 MSE 값을 보여주고 있다. 이러한 경우에도 MSE 값이 $0.01{ }^{\circ} \mathrm{C}^{2}$ 이 되는 시간이 열량투입 후 약 7 시간으로 나타났다. 그러므로 현재 수직 밀폐형 지중 열교환기에 적용되고 있는 초기제외시간 $(12 \mathrm{hr})$ 은 적절하다고 판단 된다.

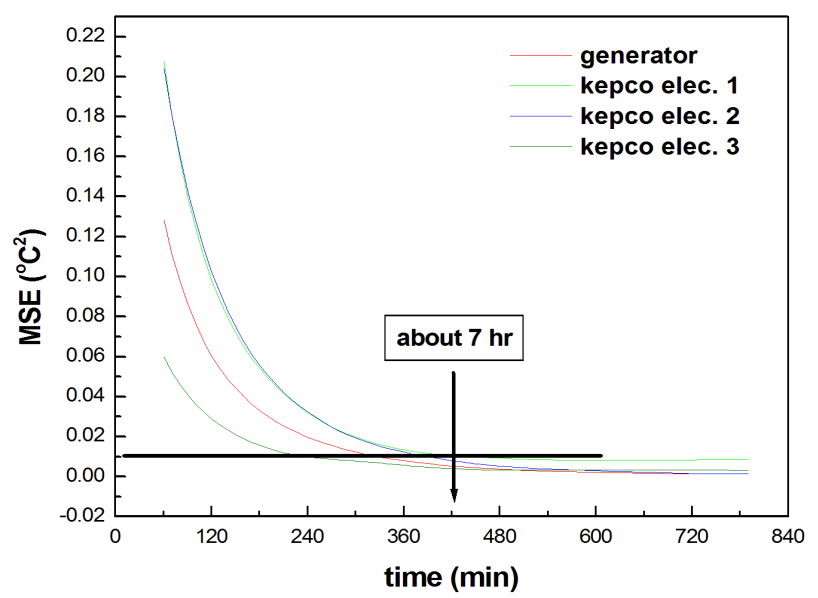

Fig. 3 Data apply IIT $=12 \mathrm{~h}$. 


\section{$3.2 \operatorname{SCW}$ 형 지중 열교환기 시험데이터를 이용한 초기제외시간 해석}

수직 밀폐형 지중 열교한기에 적용한 MSE 방법을 이용하여 SCW형 지중 열교환기를 해석해 보았다. Fig. 4는 SCW형 지중 열교환기의 시험데이터를 보여주고 있다. 시험 데이터에서 투입열량은 $87.69 \mathrm{~kW}$ 로 안정적 으로 공급되었으며, 이때 순환수 평균온도를 이용하여 오차해석을 하였다. Fig. 5 Fig. 7은 초기제외시간을 2 시간, 3 시간, 4 시간으로 각각 적용하였을 경우에 로그 시간에 따른 순환수 평균온도 직선식을 보여주고 있다. Fig. 5 에서 보면 초기제외시간을 2 시간 적용하였을 경 우 기울기는 5.10 에 지중 열전도도는 $3.42 \mathrm{~W} /(\mathrm{m} \mathrm{K})$ 로 나타났다. Fig. 6은 초기제외시간이 3시간일 경우 기울 기는 5.19 에 지중 열전도도는 $3.36 \mathrm{~W} /(\mathrm{m} \mathrm{K})$ 로 나타났 으며, Fig. 7 초기제외시간이 4시간일 경우 기울기는 5.24에 지중 열전도도는 $3.33 \mathrm{~W} /(\mathrm{m} \mathrm{K})$ 로 나타났다. 이

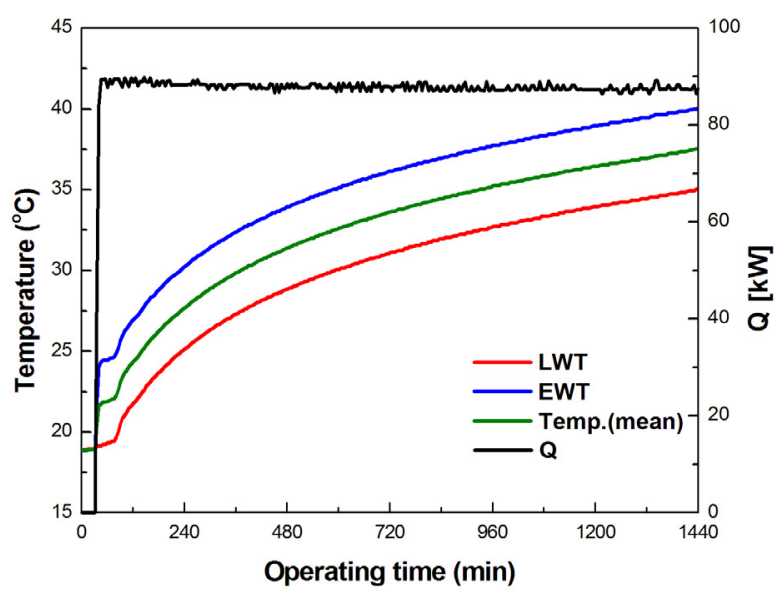

Fig. 4 Test data of SCW type ground heat exchanger(Case 8).

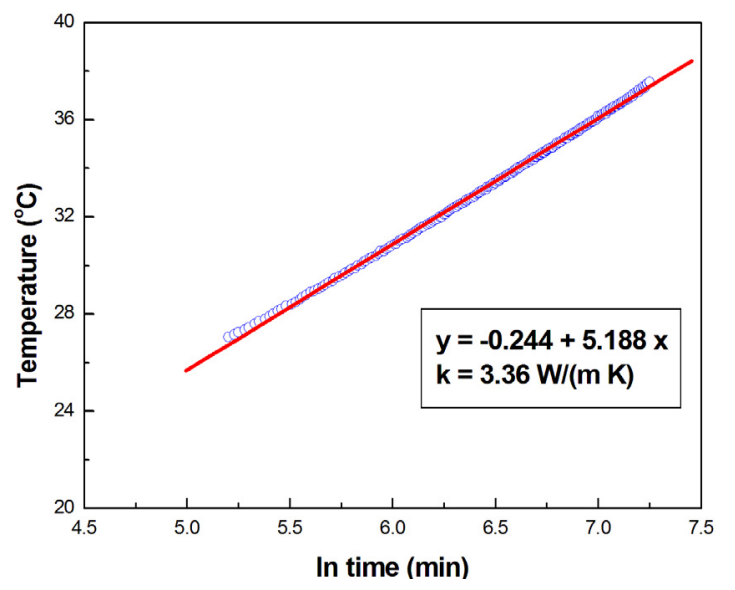

Fig. 6 T-ln t of Data apply IIT $=3 \mathrm{~h}$.
들 Fig. 5 Fig. 7에서 보면 초기제외시간이 증가할수록 그래프의 초기데이터가 직선식에 잘 수렴하는 것을 알 수 있으며, 초기제외시간이 증가하면서 $\mathrm{k}$ 값은 감소하 는 경향을 보였다. 이는 초기제외시간 2시간의 경우 암 반과 투입열량에 관계에서 아직 안정화가 이루어 지지 않은 것으로 보인다.

\subsection{SCW형 지중 열교환기 초기시간변화에 따른 오차해석}

본 연구에서는 지난 4년간 진행된 시험 데이터를 이 용하여 초기제외시간 변화에 따른 MSE 변화량을 분 석하였다. SCW형 지중 열교환기의 경우 지하수 순환 수가 지중 열교환기를 한 바퀴 순환하는 시간이 수직 밀폐형 지중 열교환기에 비해 길고, 투입열량 또한 수 직 밀폐형 지중 열교환기보다 크기 때문에 MSE 설정 값을 $0.02^{\circ} \mathrm{C}^{2}$ 으로 하였다.

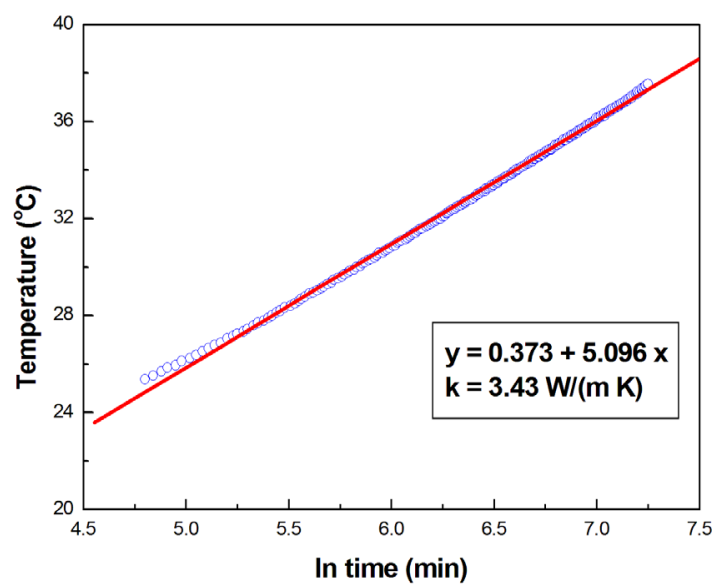

Fig. $5 \mathrm{~T}-\ln \mathrm{t}$ of Data apply IIT $=2 \mathrm{~h}$.

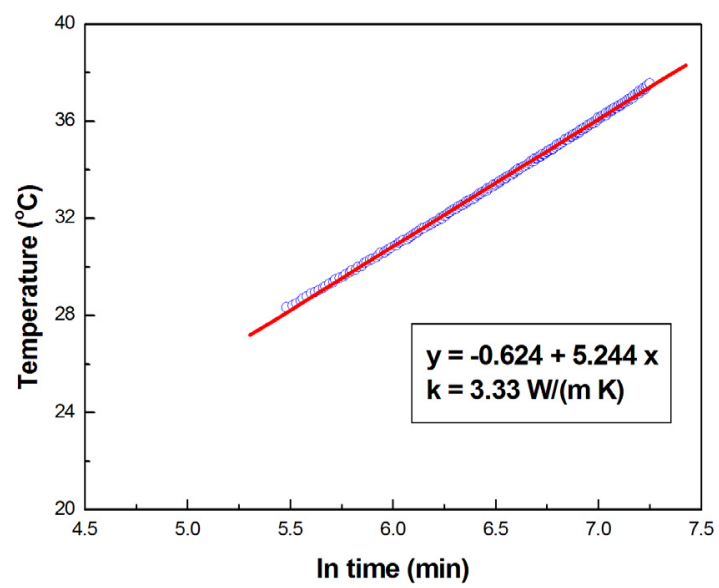

Fig. 7 T-ln t of Data apply IIT $=4 \mathrm{~h}$. 
Fig. 8은 SCW형 지중 열교환기 시험데이터에서 초 기제외시간을 2시간 적용하였을 때 시간변화에 따른 MSE 변화량을 보여주고 있다. Fig. 8에서 보면 시험초기 (열량투입 후)에 MSE 값이 크게 나타나며 시간이 흐 를수록 MSE 값이 작아지는 경향을 보인다. 그래프에 서 보면 초기제외시간 2시간에서 설정 MSE 값인 0.0 $2{ }^{\circ} \mathrm{C}^{2}$ 범위 안에 들어오지 못하는 경우들이 발생하는 것을 알 수 있다.

Fig. 9와 Fig. 10은 SCW형 지중 열교환기 시험 데이 터에서 초기제외시간을 3 시간과 4 시간 적용하였을 때 시간변화에 따른 MSE 변화량을 보여주고 있다. 초기 제외시간을 3시간(Fig. 9)과 4시간(Fig. 10) 각각 적용 하였을 때도 마찬가지로 시험초기에는 오차해석 값이 크게 발생하는 경향을 보인다. 하지만 초기제외시간 3 시간과 4시간을 적용한 그래프에서는 MSE 값이 설정 값 $\left(0.02^{\circ} \mathrm{C}^{2}\right)$ 보다 작게 나타났다. 이들 그래프에서 보면 초기제외시간이 4시간일 경우에 MSE 값이 데이터 해 석에서 가장 안정적인 것을 알 수 있다.

\section{4 초기제외시간대별 $a$ 값과 $k$ 값}

Table 2는 각 시험 데이터에서 초기제외시간을 2,3 , 4시간 적용하였을 경우에 직선의 기울기(a)값과 지중 열전도도 $(\mathrm{k})$ 값의 변화를 정리하였다. Table 2에서 타 입은 Fig. 1 에서 보여주는 $\mathrm{SCW}$ 형 지중 열교환기의 종 류를 의미한다. 표에서 Case 3번을 제외하고 모든 경 우에서 초기제외시간이 증가하면서 $\mathrm{a}$ 값은 커지고, $\mathrm{k}$ 값 은 작아지는 경향을 보인다. 초기제외시간 4시간을 기 준으로 해서 지중 열전도도 변화량이 2시간의 경우보 다 3 시간의 경우가 더 작게 나타났다. 따라서 $\mathrm{SCW}$ 형 지중 열교환기의 시험데이터에서 초기제외시간 4시간 이 가장 적절한 것으로 판단된다.

\section{4. 결 론}

본 연구에서는 국내에 적용되어지는 $\mathrm{SCW}$ 형 지중 열교환기의 지중 열전도도 측정시험을 진행하면서 적 용되어지는 초기제외시간(IIT)에 관하여 연구하였으며, 다양한 초기제외시간을 적용하여 $\mathrm{SCW}$ 형 지중 열교환 기의 지중 열전도도를 분석한 결과 다음과 같은 결론 을 얻었다.

(1) MSE 방법을 통하여 수직 밀폐형 지중 열교환기 및 $\mathrm{SCW}$ 형 지중 열교환기의 초기제외시간을 분석 하였다.

(2) 수직 밀폐형 지중 열교환기의 경우 사용전력이 발 전기와 한전수전으로 다양하게 적용되어지고 있으 나 초기제외시간을 12 시간을 적용하였을 때 $\mathrm{MSE}$ 값이 $0.01{ }^{\circ} \mathrm{C}^{2}$ 에 도달하는데 걸리는 시간이 약 7시 간으로 나타났다.

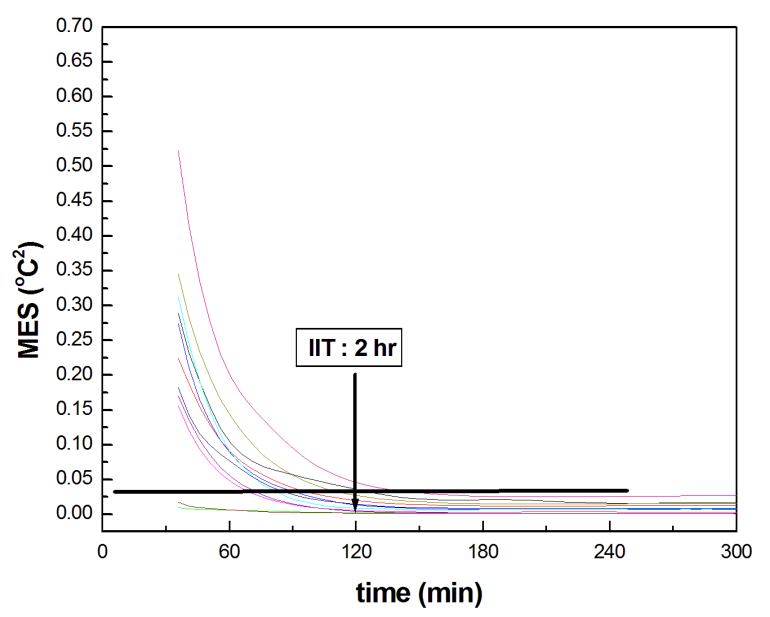

Fig. 8 MES apply IIT $=2 \mathrm{~h}$.

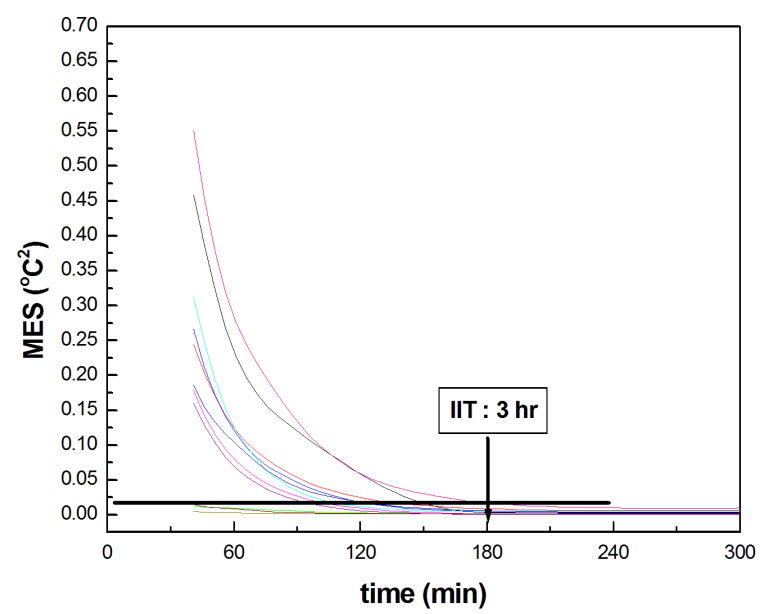

Fig. 9 MES apply IIT $=3 \mathrm{~h}$.

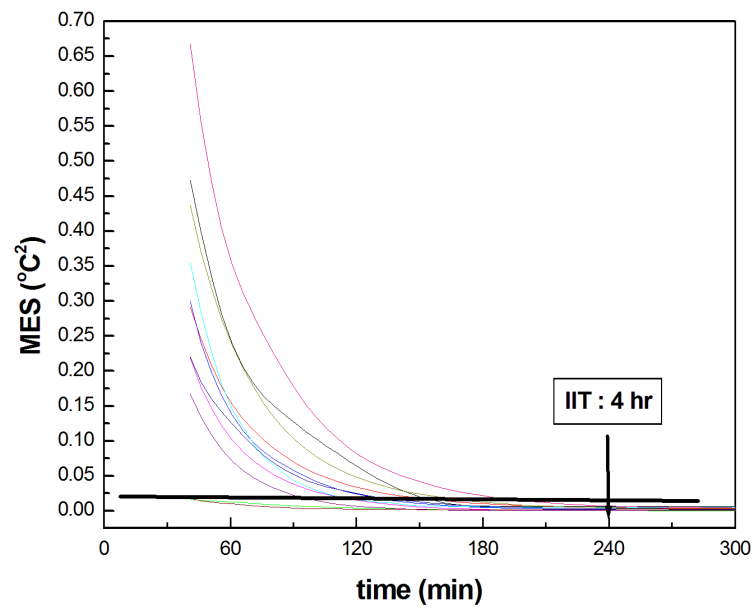

Fig. 10 MES apply IIT $=4 \mathrm{~h}$. 
Table 2 Variable a and $\mathrm{k}$ value of IIT of SCW type ground heat exchanger

\begin{tabular}{|c|c|c|c|c|c|c|c|c|c|c|c|}
\hline & \multirow[t]{2}{*}{ Type } & \multirow{2}{*}{$\begin{array}{c}\text { Bore } \\
\text { Depth }\end{array}$} & \multirow{2}{*}{$\begin{array}{l}\text { Flow } \\
\text { Rate }\end{array}$} & \multicolumn{3}{|c|}{$\mathrm{a}($ slope $)$} & \multicolumn{3}{|c|}{$\mathrm{k}(\mathrm{W} /(\mathrm{m} \mathrm{K}))$} & \multicolumn{2}{|c|}{$\frac{k_{x h}-k_{4 h}}{k_{4 h}}$} \\
\hline & & & & $2 \mathrm{~h}$ & $3 \mathrm{~h}$ & $4 \mathrm{~h}$ & $2 \mathrm{~h}$ & $3 \mathrm{~h}$ & $4 \mathrm{~h}$ & $2 \mathrm{~h}$ & $3 \mathrm{~h}$ \\
\hline Case 1 & $\mathrm{a}$ & 450 & 279 & 5.48 & 5.80 & 5.81 & 3.29 & 3.11 & 3.10 & 6.1 & 0.3 \\
\hline Case 2 & d & 295 & 226 & 5.33 & 5.44 & 5.51 & 3.14 & 3.08 & 3.04 & 3.3 & 1.3 \\
\hline Case 3 & e & 295 & 220 & 1.56 & 1.52 & 1.50 & 10.76 & 11.03 & 11.21 & -4.0 & -1.6 \\
\hline Case 4 & e & 400 & 182 & 5.90 & 6.00 & 6.05 & 2.88 & 2.83 & 2.81 & 2.5 & 0.7 \\
\hline Case 5 & $\mathrm{~b}$ & 400 & 212 & 4.74 & 4.86 & 4.92 & 3.54 & 3.45 & 3.41 & 3.8 & 1.2 \\
\hline Case 6 & $\mathrm{a}$ & 500 & 259 & 6.27 & 6.12 & 6.23 & 2.63 & 2.69 & 2.64 & -0.4 & 1.9 \\
\hline Case 7 & $\mathrm{~b}$ & 500 & 258 & 5.70 & 5.82 & 5.91 & 2.97 & 2.90 & 2.86 & 3.8 & 1.4 \\
\hline Case 8 & $\mathrm{a}$ & 400 & 250 & 5.10 & 5.19 & 5.24 & 3.42 & 3.36 & 3.33 & 2.7 & 0.9 \\
\hline Case 9 & a & 350 & 241 & 4.88 & 4.94 & 4.95 & 3.56 & 3.52 & 3.51 & 1.4 & 0.3 \\
\hline Case 10 & $\mathrm{a}$ & 423 & 273 & 2.54 & 2.56 & 2.58 & 4.47 & 4.43 & 4.40 & 1.6 & 0.7 \\
\hline
\end{tabular}

(3) $\mathrm{SCW}$ 형 지중 열교환기의 경우 초기제외시간을 2, 3,4 시간으로 적용하였을 때 2시간의 경우 MSE 값이 $0.02{ }^{\circ} \mathrm{C}^{2}$ 에 도달하지 못하는 경우가 발생하였으며, 3,4 시간에서는 발생하지 않았다.

(4) 본 연구를 통하여 분석한 결과 SCW형 지중 열교환기 의 초기제외시간은 4시간이 적절할 것으로 판단된다.

\section{후 기}

본 연구는 에너지기술평가원에서 진행하는 2014년 도 에너지기술개발사업(20143030110990)의 지원을 받 아 수행한 연구과제로 이에 감사드립니다.

\section{References}

1. Ministry of Knowledge Economy, 2012, Standards of support, Installation, and Management for New and Renewable Energy System, Ministry of Knowledge Economy Announcement, 2012-3.

2. Gehlin, S. E. A., 2002, Thermal response test -method development and evaluation, Ph.D Thesis, Lulea University of Technology, Lulea, Sweden,

3. Ingersoll, L. R., Adler, F. T., Plass, H. J., and Ingersoll, A.C., 1951, Theory of earth heat exchangers for the heat pump, ASHVE Transaction, Vol. 57, pp. 167-188.

4. Lee, S. K., Woo, J. S., and Kim, D. G., 2008, A study of Determining Initial Ignoring Time of Line Source Model used in Estimating the Effective Soil Formation Thermal Conductivities. Journal of Energy Engineering, Vol. 17, No. 3, pp. 167-174.

5. Kim, M. J. and Choi, C. H., 2013, A study on the KS (Korea Standard) of SCW type ground heat exchanger, Journal of Geothermal Energy, Vol. 9, No. 4, pp. 39-46.

6. Choi, H. S., Choi H. J., Lee, C. H., and Yun, M. S., 2013, A assessment ground thermal conductivity for SCW type ground heat exchanger design, Journal of Geothermal Energy, Vol. 9, No. 3, pp. 67-73.

7. Kim, M. J. and Chang, K. S., 2013, SCW type ground heat exchanger analysis using borehole photo shoot, Journal of Geothermal Energy, Vol. 9, No. 4, pp. 47-54. 